\title{
Biometric Study of the Bifurcations of the Popliteal Artery and the Tibiofibular Trunk
}

\author{
Estudio Biométrico de las Bifurcaciones de la Arteria Poplítea y del Tronco Tibiofibular
}

\author{
M. B. Hirano "; H. R. Teles"; T. Macedo*; E. A. Sgrott"; H. Stuker ${ }^{* * *}$; E. Olave**** \& R. S. Moreira**
}

HIRANO, M. B.; TELES, H. R.; MACEDO, T.; SGROTT, E. A.; STUKER, H.; OLAVE, E. \& MOREIRA, R. S. Biometric study

of the bifurcations of the popliteal artery and the tibiofibular trunk. Int. J. Morphol., 32(4):1383-1387, 2014.

SUMMARY: The popliteal artery is located deep inside the popliteal fossa, and is an important landmark in surgical procedures. Lesions of this vessel and its branches can be dangerous, blocking circulation to the lower limb and leading to gangrene or even vascular failure. The aim of this work was to describe the biometric characteristics of the bifurcations of the popliteal artery and the tibiofibular trunk in relation to the head of the fibula in 38 lower limbs through dissection. The bifurcation of the both arteries was present in all the cases. The mean confidence interval for the bifurcation of the popliteal artery was from $2.82 \mathrm{~cm}$ to $3.18 \mathrm{~cm}$ from the head of the fibula, and that of the bifurcation of the tibiofibular trunk was from $5.72 \mathrm{~cm}$ to $6.68 \mathrm{~cm}$. The bifurcation of the popliteal artery into the anterior tibial artery and tibiofibular trunk showed a more constant positioning than the level of the birfurcation of the posterior tibial artery and fibular artery. These data can help in the development of new access routes to these arteries, or the optimization of surgical planning in the region in question.

KEY WORDS: Anatomy; Lower limb; Popliteal region; Popliteal artery.

\section{INTRODUCTION}

Knowledge of the variability of the vascular anatomy of the popliteal region is fundamental for surgeons and those who work with vascularization of the lower limb. Much attention has been given to the morphology of the popliteal artery, its branches, and its relationship to the anatomical structures around it (Latiff \& Das, 2009) due to its importance and influence in some clinical and surgical conditions, such as high tibial osteotomies, arthroplasties, atherosclerotic popliteal aneurysms (Zaidi et al., 1995), transluminal angioplasty, diagnoses of arterial lesion, and entrapment syndrome (Tanaka et al., 2010).

In this context, the popliteal artery is the second most commonly affected vessel in lesions of the lower limb (Meirelles, 2003). The close relationship of this artery with the femur and the tibia in the knee region explains the vascular lesions commonly associated with fractures and dislocations of this joint. Another associated cause is iatrogenic. Knowledge of the pattern and variation in the vessels can help prevent vascular lesions associated with surgeries of the knee or upper third of the tibia (e.g.: high tibial osteotomies, arthroplasties) (Day \& Orme, 2006). Although the frequency of these lesions is low during surgical procedures, when they do occur they are generally severe, resulting in ischemia, hemorrhages, fistulas, and even arteriovenous amputation (Kesser et al. 2006).

Anatomical variations in the popliteal arterial system influence the prognosis of many surgical procedures in the region of the knee joint. Although the two most common variations are the termination of the popliteal artery in a trifurcation instead of a bifurcation, and the division of its branches at an anatomically higher region than normal, in the region of the knee joint (Kim et al., 1989), nine patterns of variations are described in the literature (Mavili et al., 2011). The change that can lead to an increase in transoperative accidents occuring in around 5\% of cases, where there is a high bifurcation in the posterior region of the knee (Ozgur et al., 2009).

\footnotetext{
* Graduate students of the Medicine, Faculty of Medicine, Center for Health Sciences, University of Vale do Itajaí, Itajai, Brazil.

** Professor of the Human Anatomy Discipline, Faculty of Medicine, Center for Health Sciences, University of Vale do Itajaí, Itajai, Brazil.

**** Professor of the Biostatistics Discipline, Faculty of Dentistry, Center for Health Sciences, University of Vale do Itajaí, Itajai, Brazil.

*****Facultad de Medicina, Universidad de La Frontera, Temuco, Chile.
} 
An anomalous relationship between the popliteal artery with the adjacent musculotendinous structures can lead to entrapment syndrome of the popliteal artery (Gourgiotis et al., 2008) and complications in procedures related to arterial reconstruction that require graft and femorodistal bypass procedures (Kim et al.).

Through a literature review, none of the works evaluated described a point of reference for identifying the height of the bifurcation of the popliteal artery that uses a cutaneous landmark. The objective of this work was to evaluate the pattern of bifurcation of the popliteal artery and in the leg, measuring the distance of its bifurcations relative to a cutaneous landmark, the head of the fibula.

\section{MATERIAL AND METHOD}

Thirty-eight lower limbs were dissected, from 19 cadavers ( 6 male and 13 female) belonging to the Anatomy Laboratory of the University of Vale do Itajaí with prior approval of the Research Ethics Committee of UNIVALI (CEP Opinion 106/11). This is a descriptive and quantitative work. A criteria for inclusion was that no sample should

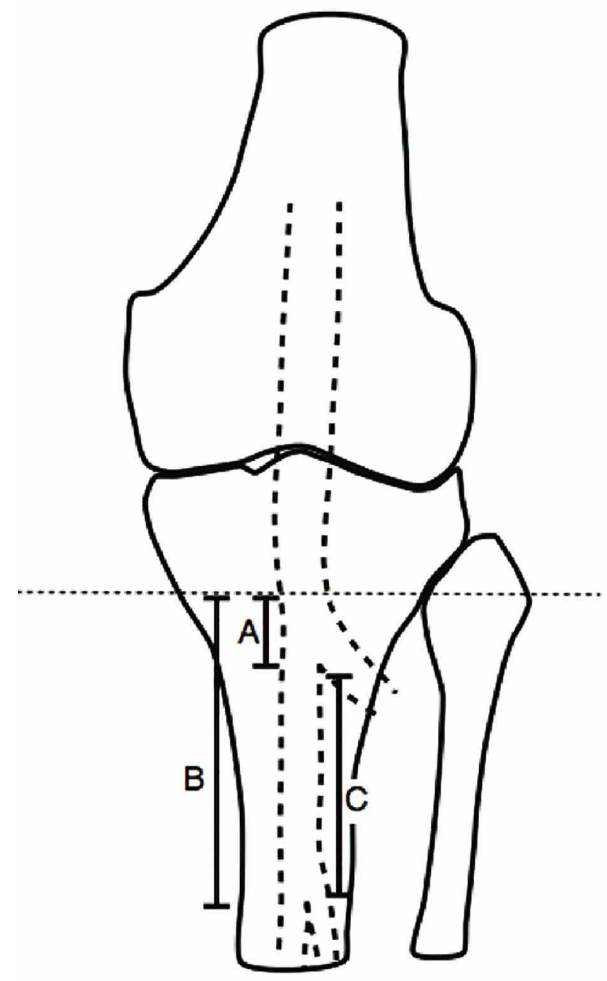

Fig. 1. The distance from the first branch (A) and from the second branch (B) to the head of the fibula in the cranialcaudal direction, and the length of the trunk (tibiofibular) (C) present signs of previous vascular surgery in the region. Prior to dissection, the cutaneous landmark (most lateral part of the head of the fibula) was marked with a pin. From this landmark, a line was drawn on the horizontal plane (Fig. 1). This landmark was chosen because it can be easily identified by cutaneous palpation.

To access the popliteal artery and its branches, an incision was made in the skin and superficial fascia of the popliteal fossa, and the superficial structures were dissected to expose the vessels in question. Reference markers were inserted in the point of origin of the anterior tibial artery, in the bifurcation of the tibiofibular trunk and in the anatomical landmark (fibula) (Fig. 2).

The distances between the marked point, at the height of the bifurcation of the tibiofibular trunk and anterior tibia were measured with a digital caliper. For the purposes of classification, a bifurcation was classified as high if its origin was close to the lower margin of the popliteal muscle (Kim et al.). After all the measurements were complete, the data were plotted and the statistical analysis performed.

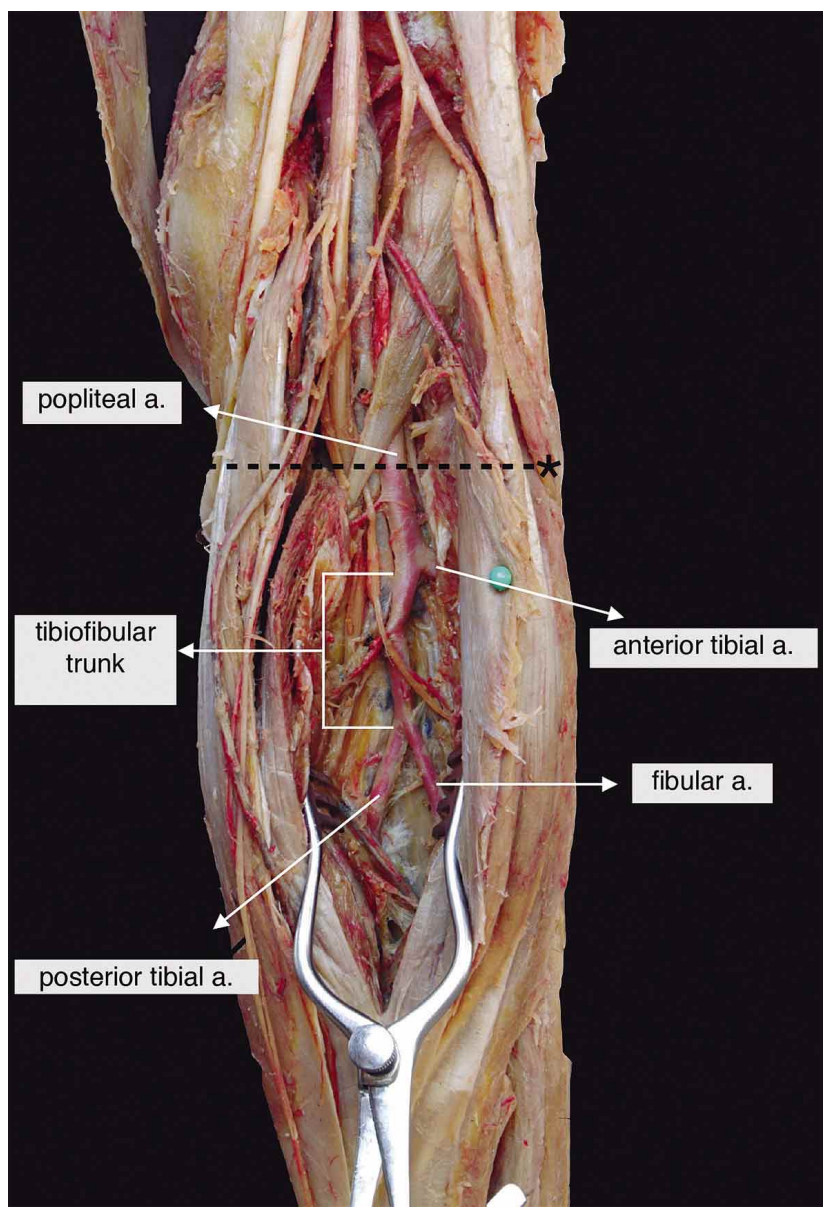

Fig. 2. Dissection of the popliteal fossae with the reference points marked. Black star is the most lateral part of the head of the fibula. 


\section{RESULTS}

The results are summarized in Table I. There were no statistically significant differences, for the two measurements, between the measurements obtained in male and female cadavers, or between the right and left sides of the same cadaver (Table II). The mean distance of the horizontal plan that crosses the most lateral part of the head of the fibula to the popliteal artery bifurcation in anterior tibial artery and tibiofibular trunk was $3.0 \pm 0.6 \mathrm{~cm}$ (mean \pm standard deviation). The bifurcation of the tibiofibular trunk in the posterior tibial artery and fibular artery was $6.2 \pm 1.5 \mathrm{~cm}$, distally to the plane of the head of the fibula. Both bifurcations were presented in all cases. On average, the tibiofibular trunk has a mean length of $3.2 \pm 1.4 \mathrm{~cm}$. All the bifurcations were classified as normal (type I-A), according to Kim et al. No trifurcations were found, or any other types of variation. In two samples, the tibiofibular trunk measured less than $1 \mathrm{~cm}$ in length, and in another 4 , the trunks were long, measuring more than $5 \mathrm{~cm}$ in length (Fig. 3).

\section{DISCUSSION}

Recognition of the possible locations and anatomical variations is important for planning imaging exams or surgical interventions (Day \& Orme). Although some researches give an extensive description of the relationships between the vascular structures studied here (Szpinda, 2005; Tindall et al., 2006; Latiff \& Das; Kil \& Jung, 2009; Ozgur et al.; Day \& Orme; Mavili et al.), none of them correlate a cutaneous landmark for the localization of the bifurcations.

The use of a cutaneous landmark is justified as it offers a point of easy access and localization, to access the vessels in question in emergency cases, to estimate the height of its bifurcation when it is not possible to carry out imaging exams prior to surgery.

The small standard deviation presented for the first branch shows that its anatomical position is more constant, unlike the second bifurcation, where the origin of the fibular artery is variable (Mauro et al., 1988). The results showed no statistically significant differences between men and women, and between the right and left limbs.
Table I. Measurements obtained based on the distance from the horizontal plane of the head of the fibula to the arterial divisions (in $\mathrm{cm}$ ).

\begin{tabular}{lccc}
\hline & 1st branch $($ A) & 2nd branch $(B)$ & Trunk $(\mathrm{C})$ \\
\hline Samples & $\mathbf{3 8}$ & $\mathbf{3 8}$ & $\mathbf{3 8}$ \\
Minimum (cm) & $\mathbf{1 . 9}$ & $\mathbf{3 . 1}$ & $\mathbf{0 . 4}$ \\
Maximum (cm) & $\mathbf{4 . 3}$ & $\mathbf{1 0 . 1}$ & $\mathbf{7 . 6}$ \\
Mean $(\mathrm{cm})$ & $\mathbf{3 . 0}$ & $\mathbf{6 . 2}$ & $\mathbf{3 . 2}$ \\
Standard Deviation $(\mathrm{cm})$ & $\mathbf{0 . 5 6}$ & $\mathbf{1 . 5 0}$ & $\mathbf{1 . 4}$ \\
Standard Error $(\mathrm{cm})$ & 0.18 & 0.48 & 0.46 \\
\hline
\end{tabular}

Table II. Student t test, comparing the measurements of the first and second bifurcations between male and female and between right and left.

\begin{tabular}{lcc}
\hline & 1 st branch $(\mathbf{A})$ & 2nd branch $(\mathbf{B})$ \\
\hline Male and Female & 0.874 & 0.228 \\
Right and Left sides & 0.486 & 0.331 \\
\hline
\end{tabular}

$\overline{\mathrm{p}<0.01}$

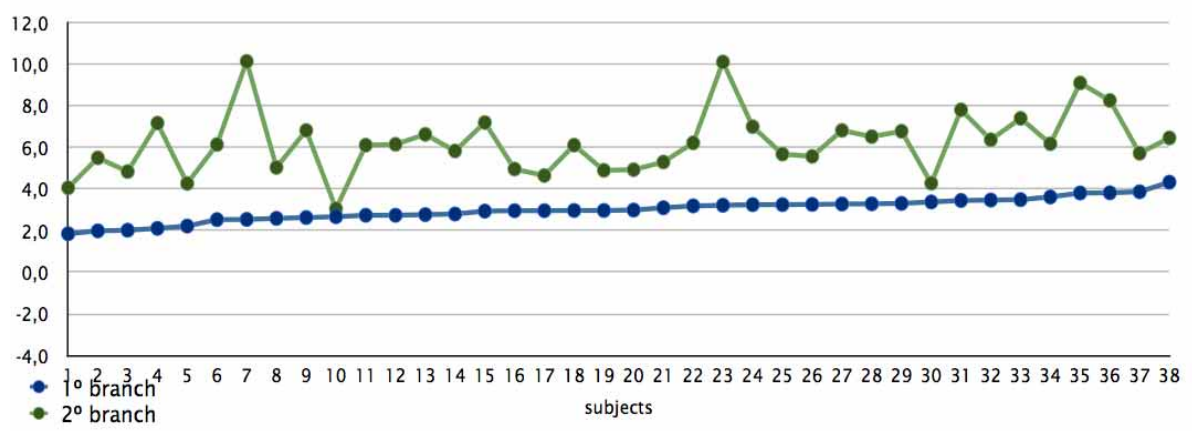

Fig. 3. Measurements (in $\mathrm{cm}$ ) of the first and second branches of the popliteal artery from the fibular plane of reference. * Zero represents the horizontal plan that passes through the most lateral part of the head of the fibula.
Then greatest inconsistency of this positioning is related to the variability in length of the tibiofibular trunk. The mean confidence interval for the first bifurcation was 1.9 $\mathrm{cm}$ to $4.1 \mathrm{~cm}$ and for the second bifurcation; it ranged from 3.2 $\mathrm{cm}$ to $9.2 \mathrm{~cm}$. Thus, like Szpinda, we found short and long tibiofibular trunk, with no statistically significant difference between the two sides. However the long trunk described by us were not associated with high origins of the popliteal artery (above the joint line of the knee) (Kim et al.; Szpinda; Day \& Orme). A total of 4 trunks $(10.5 \%)$ measured more than $5 \mathrm{~cm}$. The length of the tibiofibular trunk was $3.2 \pm 1.4 \mathrm{~cm}$, very close to the measurements found by Ozgur et al. $(3.0 \pm 1.6 \mathrm{~cm})$. Sanders \& Alston (1986) described that in $87 \%$ of samples, the tibiofibular trunk presented a length of 2 to $5 \mathrm{~cm}$, while in our sample, we found $76.3 \%$ (29 cases). 
The percentage of samples that presented a tibiofibular trunk of less than $1 \mathrm{~cm}$ was 5.3\% (2 samples). This figure was no different from that presented by Ozgur et al., but a little lower than that demonstrated by Cross et al., (2000) which was $8 \%$.

The importance of predicting or estimating the size of the trunk and position of the bifurcations lies in the fact that regardless of whether the pattern of the bifurcation is altered due to embryological defects, ethnic variability or even acquired by nature, these variations directly influence surgical procedures in this region (Latiff \& Das).

This work is the first report, as far as we are aware, of a measurement of the bifurcation of the popliteal artery (first and second branches) relative to a cutaneous landmark.

Although the measurements are similar to those of the work of Ozgur et al., in this work, we define measurements in relation to a cutaneous reference point that is easily palpable. The first bifurcation showed a more constant anatomical position, approximately $3 \mathrm{~cm}$ below the horizontal plan, which passes through the head of the fibula. The second bifurcation was more variable, within the limits of 3.1 to $10.1 \mathrm{~cm}$ from the fibular plane.

The different positions of the artery in the region of the popliteal fossa and its channel are related to the embrionary vascular development, which determines the anatomical variability, as the embrionary vessels may persist, degenerate, or merge to form abnormal anastomoses (Latiff \& Das).

Through the analysis of the data described, it is possible to propose a cutaneous anatomical mark - the head of the fibula - as a point of reference for optimizing access to the first bifurcation in a surgical approach.

\section{ACKNOWLEDGEMENTS}

This work was financed by the Bolsa de Pesquisa (Research Grant) program (Article 170) of the University of Vale do Itajaí, Brazil.

HIRANO, M. B.; TELES, H. R.; MACEDO, T.; SGROTT, E.A.; STUKER, H.; OLAVE, E. \& MOREIRA, R. S. Estudio biométrico de las bifurcaciones de la arteria poplítea y del tronco tibiofibular. Int. J. Morphol., 32(4):1383-1387, 2014.

RESUMEN: La arteria poplítea se encuentra en la fosa del mismo nombre y es un punto de referencia importante en los procedimientos quirúrgicos. Las lesiones de este vaso y sus ramas pueden ser peligrosas, bloqueando la circulación a la extremidad inferior pudiendo llevar a gangrena o incluso a la insuficiencia vascular. El objetivo de este trabajo fue describir la anatomía de la arteria poplítea y el nivel de su primera bifurcación en tronco tibiofibular y arteria tibial anterior, y además el nivel de bifurcación del tronco en arterias tibial posterior y fibular (segunda bifurcación), en relación a la cabeza de la fíbula. Para ello se realizó disección en 38 miembros inferiores. El intervalo de confianza para la media de la primera bifurcación fue de 2,82 cm a 3,18 cm de la cabeza de la fíbula y la de la segunda bifurcación fue de $5,72 \mathrm{~cm}$ a $6,68 \mathrm{~cm}$. La bifurcación de la arteria poplítea en la arteria tibial anterior y el tronco tibiofibular mostró un posicionamiento más constante que la altura de la bifurción de la arteria tibial posterior y la arteria fibular. Estos datos pueden ayudar en el desarrollo de nuevas vías de acceso a estas arterias, o la optimización de la planificación quirúrgica de la región.

PALABRAS CLAVE: Anatomía; Miembro inferior; Región poplitea; Arteria poplítea.

\section{REFERENCES}

Cross, L.; Hall, J.; Howdieshell, T. R.; Colborn, G. L. \& Gale, T. F. Clinical anatomy of the popliteal blood vessels. Clin. Anat., 13(5):347-53, 2000

Day, C. P. \& Orme, R. Popliteal artery branching patterns -- an angiographic study. Clin. Radiol., 61(8):696-9, 2006.

Gourgiotis, S.; Aggelakas, J.; Salemis, N.; Elias, C. \& Georgiou, C. Diagnosis and surgical approach of popliteal artery entrapment syndrome: a retrospective study. Vasc. Health Risk Manag., 4(1):83-8, 2008.
Kesser, S.; Savranlar, A.; Bayar, A.; Ulukent, S. C.; Ozer, T. \& Tuncay, I. Anatomic localization of the popliteal artery at the level of the knee joint: a magnetic resonance imaging study. Arthroscopy, 22(6):656-9, 2006.

Kil, S. W. \& Jung, G. S. Anatomical variations of the popliteal artery and its tibial branches: analysis in 1242 extremities. Cardiovasc. Intervent. Radiol., 32(2):233-40, 2009.

Kim, D.; Orron, D. E. \& Skillman, J. J. Surgical significance of popliteal arterial variants. A unified angiographic classification. 
HIRANO, M. B.; TELES, H. R.; MACEDO, T.; SGROTT, E. A.; STUKER, H.; OLAVE, E. \& MOREIRA, R. S. Biometric study of the bifurcations of the popliteal artery and the tibiofibular trunk. Int. J. Morphol., 32(4):1383-1387, 2014.

Ann. Surg., 210(6):776-81, 1989.

Latiff, A. A. \& Das, S. Anatomical insight into the normal and abnormal branching pattern of the popliteal artery. Surg. Radiol. Anat., 31(7):563-4, 2009.

Mauro, M. A.; Jaques, P. F. \& Moore, M. The popliteal artery and its branches: embryologic basis of normal and variant anatomy. AJR Am. J. Roentgenol., 150(2):435-7, 1988.

Mavili, E.; Dönmez, H.; Kahriman, G.; Özas lamacı, A.; Özcan, N. \& Tasdemir, K. Popliteal artery branching patterns detected by digital subtraction angiography. Diagn. Interv. Radiol., 17(1):80-3, 2011.

Meirelles, S. S. L. Traumatismo arterial dos membros inferiores: diagnóstico e tratamento. In: Brandão Pitta, G. B.; Araújo Castro, A. \& Burihan, E. (Eds.). Angiologia e cirurgia vascular: guia ilustrado. Maceió, UNCISAL/ECMAL \& LAVA, 2003. Available in: http://www.lava.com.br/livro/

Ozgur, Z.; Ucerler, H. \& Aktan Ikiz, Z. A. Branching patterns of the popliteal artery and its clinical importance. Surg. Radiol. Anat., 31(5):357-62, 2009.

Sanders, R. J. \& Alston, G. K. Variations and anomalies of the popliteal and tibial arteries. Am. J. Surg., 152(5):531-4, 1986.

Szpinda, M. Angiographic study of the tibioperoneal trunks in patients with aorto-iliac occlusive disease. Ann. Anat., 187(4):405-10, 2005.

Tanaka, H.; Higashi, M.; Fukumoto, Y. \& Ogino, H. Entrapment of the popliteal artery. J. Vasc. Surg., 52(2):479, 2010.

Tindall, A. J.; Shetty, A. A.; James, K. D.; Middleton, A. \& Fernando, K. W. Prevalence and surgical significance of a highorigin anterior tibial artery. J. Orthop. Surg. (Hong Kong), 14(1):13-6, 2006.

Zaidi, S. H.; Cobb, A. G. \& Bentley G. Danger to the popliteal artery in high tibial osteotomy. J. Bone Joint Surg. Br., 77(3):384-6, 1995.
Correspondence to:

Rafael Saviolo Moreira

Rua Almirante Barroso, 1265 sala 3

Vila Nova - Blumenau

89035-402

BRAZIL

Email: rsaviolo@me.com / rsaviolo@univali.br

Received: 21-04-2014

Accepted: 21-10-2014 